\title{
The effects of landscape history and time-lags on plant invasion in Mediterranean coastal habitats
}

Author link to publication: http://rdcu.be/mva5

Journal link to publication: http://ink.springer.com/article/10.1007/s10530-016-1314-Z

González-Moreno, Pablo ${ }^{1,2^{*}}$; Pino, Joan ${ }^{3,4}$; Cózar, Andrés ${ }^{5}$; García de Lomas, Juan ${ }^{6}$; Vilà, Montserrat ${ }^{1}$

${ }^{1}$ Estación Biológica de Doñana (EBD-CSIC), Av. América Vespucio s/n, Isla de la Cartuja, 41092 Sevilla, Spain.

${ }^{2}$ CABI, Bakeham Lane, Egham TW20 9TY, UK

${ }^{3}$ CREAF, Cerdanyola del Vallès 08193, Spain

${ }^{4}$ Univ Autònoma Barcelona, Cerdanyola del Vallès 08193, Spain

${ }^{5}$ Departamento de Biología, Facultad de Cc. del Mar y Ambientales, Universidad de Cádiz, E-11510 Puerto Real, Spain

${ }^{6}$ Agencia Andaluza de Medio Ambiente y Agua. C/ Johan G. Gutenberg, 1, 41092 Sevilla, Spain.

\begin{abstract}
Human-driven landscape changes may promote plant invasions by increasing propagule pressure and providing favourable conditions for non-native species to establish and spread. The increase in invasion levels might not be immediate but rather exhibit a time-lag (i.e. invasion debt). Moreover, the relationship between invasion and landscape history (i.e. changes in landscape composition) might be extremely complex as it might also include extinction debts of invasive species currently in regression. In order to understand the effect of landscape history on plant invasion, we studied the invasion level in coastal plant communities affected by intense human-driven landscape alteration in the last 50 years. We identified all non-native plant species within 809 grid cells (250x250 $\mathrm{m}$ ) along $\sim 500 \mathrm{~km}$ of the Spanish SW coast. We tested the association of (1) non-native richness conditional on the overall presence of non-natives (at least one species), and (2) the occurrence of the most frequent non-native species, with the percentage of human land-cover categories in 1956, 1991 and 2007 using a multimodel inference approach. We used these models to project future invasion patterns in the region. We found non-native richness to be more associated with land-cover variables in 1956 than in 2007, suggesting the existence of an invasion debt, but not for the overall presence of non-natives. For most frequent species, the effects of past landscape alteration depended on the introduction pathway and the region of origin. Species used in agriculture were more related to past cropland area, while most of the species used in gardening or forestry showed higher affinity for recently altered areas. These results highlight the relevance of the species' introduction history and landscape history in assessing future long-term invasion trends.
\end{abstract}

Key words: agriculture; introduction pathway; land-cover change; non-native plants; time-lag; urbanization. 


\section{INTRODUCTION}

Landscape structure and composition strongly influence the vulnerability of habitats to invasions (Vilà and Ibáñez 2011; González-Moreno et al. 2013b). Specifically, human land-cover areas such as cropland, built-up areas and forest plantations, bring about an increase in propagule pressure and disturbance, favouring the establishment of non-native plant species (Ohlemüller et al. 2006; Gavier-Pizarro et al. 2010). Landscapes are highly dynamic, with changes at different time scales that might determine variations in the establishment of non-native species (DeGasperis and Motzkin 2007; Ficetola et al. 2010). In fact, as the invasion process might take long (Kowarik 1995; Bennett et al. 2012), recent human-driven landscape alteration might not have an immediate effect on the current abundance or number of non-native species, but rather might determine community changes in the future (Vilà and Ibáñez 2011; Essl et al. 2011). The phenomenon that current patterns of nonnative species may better reflect historical rather than contemporary human activities has been called "invasion debt” (Essl et al. 2011; Essl et al. 2015). These lagged responses of non-native species play a key role at several stages of invasion. For example, there is a time lag between the introduction of a non-native species and their escape to natural areas (Pysek al. 1995) or between establishment and spread (Aikio et al. 2010; Essl et al. 2015).

Invasion debt can be considered at both species and community levels and it is a particular case of immigration credit (i.e. the time-lag in species colonization after a forcing event affecting habitat conditions; Cristofoli et al. 2010; Jackson and Sax 2010; Piqueray et al. 2011). Both immigration credit and invasion debt are "accrued" through the regional pools of native and non-native species, respectively, which include specific species pools ecologically suitable for particular habitats (Pärtel et al. 2011). However, the alien species pool in a given area might change much faster over time than for native species, as it is constantly enriched by newly introduced species that succesed to establish and spread (Essl et al. 2015). This aspect could hamper the identification of invasion debt at the community level, as it may be highly influenced by the interaction between the history of introduction of the species (e.g. time since introduction and introduction pathway) and the history of changes in the landscape. For instance, we would expect an association between the current occurrence of non-native escaped agricultural species and past cropland area, or between current non-native ornamental species' occurrence and past urban development (González-Moreno et al. 2013a). Exploring the association between the occurrence of the most frequent non-native species and past landscape change could reveal species-dependent patterns in community invasion dynamics.

Invasion debt is not the only delayed biodiversity response following changes in the landscape. Extinction debts, defined as a set of extant species predicted to become extinct when species community readjusts after an environmental disturbance, are common in habitats that are in regression as a result of these changes (Tilman et al. 1994; Kuussaari et al. 2009). In plants, extinction debt is a widespread phenomenon (e.g. Cousins, 2009; Hahs et al., 2009; Krauss et al., 2010), particularly among habitat specialists (Krauss et al. 2010). Although no empirical evidence is available, extinction debt related to landscape history might also affect non-native species pools, especially when non-native species are restricted to formerly abundant habitats that are now in regression. This might be the case of habitats affected by wildfires, as the subsequent vegetation recovery has been reported as a major constraint of non-native species persistence in the burned 
stands (Keeley et al., 2005; Pino et al. 2013).

In this study, we used an extensive field survey of non-native plants along $~ 500 \mathrm{~km}$ of the Southwestern coast of Spain to examine the invasion degree in plant communities with different histories of landscape alteration. In the last 50 years, Spanish coastal areas have been exposed to an intense process of urbanization linked to a substantial increase in plant invasions (Sobrino et al. 2009; Basnou et al. 2015). Therefore, this study area is an ideal case to study the effect of landscape alteration on the dynamics of biological invasions. The existence of extinction and invasion debts in the study area can be identified if current non-native distribution is stronger associated with past landscape characteristics than with current ones (Essl et al. 2011). We used this approach to unravel the effects of human-driven landscape alteration from 1956 to 2007 on (1) non-native richness conditional on the overall presence of non-natives (i.e. at least one species), and (2) the occurrence of the most frequent non-native species. We expected little delayed effects after landscape changes on the overall presence of non-natives as there is high probability that at least one species might become established soon after the changes. In contrast, we hypothesized an overall invasion debt for non-native richness, yet affected by the variability in time-lag responses across species (Kowarik 1995; Pyšek et al. 2003; Crooks 2005; Gassó et al. 2009). This approach might be further extended to project future non-natives occurrence or richness (Ficetola et al. 2010). Current landscape composition might be used in projecting future invasion if past landscapes successfully predict current invasion, providing an estimate of the balance between invasion and extinction debt yet to "accrue” (e.g. future increase, decrease or zero-sum in non-native species richness). As an example of its applicability, we projected models calibrated with past landscape data but fed with current data to estimate the potential non-native richness in the near future.

\section{METHODS}

\section{Study area}

The study was conducted on the South-western coast of Spain (Andalusia) covering $~ 500 \mathrm{~km}$ of the Atlantic coastline from Isla Cristina $\left(37^{\circ} 11^{\prime} 40^{\prime \prime} \mathrm{N}, 7^{\circ} 19^{\prime} 50^{\prime \prime} \mathrm{W}\right)$ in the West to Sotogrande (36 $6^{\circ} 18^{\prime} 43^{\prime \prime} \mathrm{N}, 5^{\circ} 15^{\prime} 10^{\prime \prime} \mathrm{W}$ ) in the East (Fig. 1A). The climate of the study region is typically Mediterranean, with warm and dry summers and mild winters. The coast is characterized by large sandy areas with some rocky areas, particularly towards the East. The coastline is fragmented by several large wetland systems (Guadalquivir and Odiel marshlands), urban areas, ports and industrial zones. Most urban expansion involved the development of urbanizations (largely summer residential homes) and chemical companies (located in industrial clusters). Forestry programs were developed throughout the 20 $0^{\text {th }}$ Century (being especially intense between 1940 and 1970) (Martínez et al. 2004; Gracia et al. 2011), whereas agricultural development in coastal areas has been heterogeneous. During the last few decades, croplands have been frequently replaced by coastal urbanizations, whereas new agricultural plots (e.g. strawberry greenhouses and rice paddies) have been established close to the Guadalquivir marshlands.

\section{Vegetation data}

In spring 2010 and 2011, we performed a non-native plant survey in the study area in collaboration with the Andalusian Environmental Administration. The occurrence of non-native plants was 
quantified by walking transects along the coastal vegetation of the entire study region (Fig. 1B). Coastal vegetation was defined as any natural vegetation (i.e. dunes and salt marshlands) located between the shoreline and any inland vegetation (i.e. species with low tolerance to salinity). Human transformed vegetation, such as gardens or plantations, was excluded from sampling. Walking transects were located at a distance of $50 \mathrm{~m}$ from the shoreline. If the coastal vegetation stripe was wider than $100 \mathrm{~m}$, a parallel transect was also placed towards inland at approximate $50 \mathrm{~m}$ from the previous transect. Due to accessibility problems (e.g. military areas) or lack of coastal vegetation in highly urbanized areas, we sampled $326 \mathrm{~km}$ of the $500 \mathrm{~km}$ total coast line. Within a $25 \mathrm{~m}$ buffer around each transect all neophytes (i.e. non-native plants introduced after 1500 A.C) according to Valdés et al. (1987) and without evidence of cultivation were identified and georeferenced (i.e. GPS coordinates). We considered both non-native invasive and naturalized species as we wanted to focus also on species at early stages in the invasion process. To standardize the data, species occurrences and transects were spatially intersected with a grid of $250 \mathrm{~m}$ x $250 \mathrm{~m}$ cells following the UTM system (Fig. 1B). Due to the sinuosity of the coastline, transect length within each cell was variable (minimum 250 m, mean 403 m maximum 1180 m). In total, we collected data from 809 grid cells.

\section{Explanatory variables}

Human-driven landscape alteration in each cell was assessed using the land-cover maps for Andalusia of 1956, 1991 and 2007, based on ortho-rectified aerial pictures and Landsat images (Moreira et al. 2010). The interpretation scale was 1:25,000 for 1956 and 2007 and 1:50,000 for 1991. We considered four land-cover variables related to landscape alteration by human activities: cropland, low-density urban (i.e. mixed garden and building areas such as single-family housing areas and tourist resorts), high-density urban (mainly built-up areas) and Eucalyptus spp. plantations (hereafter plantations). We calculated the percentage of area occupied by each landcover type in each year within each cell (i.e. zero distance) and within a buffer of 250, 500, 1000, 2000, 3000, 4000 and $5000 \mathrm{~m}$ from the cell border (i.e. spatial extent). Scale differences among aerial photographs from different years could affect the detectability of small land-use patches. For instance, the smallest patch for low-density urban cover in the study area was 0.32 ha in 1991 $(1: 50,000)$ and 0.03 ha in 2007 (1:25,000). However, effects on the percentage of each land cover category in each buffer can be considered negligible as this detectability threshold corresponds to less than $0.02 \%$ of the area in the smallest $(250 \mathrm{~m})$ buffer.

To control for the amount of current coastal vegetation in each cell, we quantified the percentage of area occupied in 2007 by the two main habitat types within each grid cell (i.e. saltmarsh and dune plant communities). Similarly, to control for differences in the management of non-native species across space, we calculated the percentage of protected areas within each cell and at the seven buffer distances. We also calculated the transect length sampled within each grid cell to account for sampling effort. Finally, climate data was obtained from the UNEX Spatial Data Infrastructure (http://secad.unex.es/conocimiento/), which provides average monthly precipitation as well as minimum and maximum temperatures at 1-km grid resolution across Spain for the period 19712007. From this dataset we extracted 19 bioclimatic variables for each cell using the R-package DISMO (Table 1). 
Prior to modelling, for each land-cover and protected area variable, we selected the spatial extent that was most influential to the invasion metrics (Table 1). The selection was based on the percentage of the deviance explained by univariate Generalized Linear Models (GLM) between each variable and both non-native presence and richness at each buffer distance from the cell border (Fig A1; see section below for model specifications). As a compromise between presence and richness patterns we selected $500 \mathrm{~m}$ as the best spatial extent for the percentages of plantation, cropland and urban areas. For the percentage of protected area, we kept the value within the cell (Fig A1). Collinearity among all predictors was checked by pair-wise Pearson's correlation tests (Table A1-2). We selected variables with a pair-wise correlation lower than 0.6. From the sets of highly correlated variables, we selected those with the widest use in the literature and clearest biological meaning. Protected area and all land-cover variables were selected, while minimum temperature of the coldest month (i.e. minimum temperature hereafter), annual precipitation and summer precipitation were selected among the climate variables (Table 1).

\section{Data analyses}

\section{Response variables}

We calculated the total non-native plant species richness in all 809 cells and applied a two-step modelling process commonly used to analyse zero-inflated count data (Zuur et al. 2009). The analysis is run first on presence/absence of any non-native species (809 cells; 362 with presence) and then on richness given the presence of at least one non-native species (362 cells); hereafter overall non-native presence and non-native richness respectively. These modelling steps are surrogates for two stages of the invasion process at community level (Polce et al., 2011; Catford et al., 2011, González-Moreno et al., 2014). The presence of any non-native plant would inform about the likelihood of recruitment of at least an individual plant. In contrast, the magnitude of the recruitment of new species would inform about a later phase in the invasion process where given suitable ecological conditions, non-native species are becoming dominant in the community. This modelling approach overcomes the problems caused with zero-inflated count data such as overdispersion and bias in the estimation of the model's parameters (Zuur et al. 2009, Catford et al., 2011).

For the most frequent non-native plants species (i.e. present in more than 29 cells) we calculated their occurrence in each cell (i.e. presence or absence in the transects within each cell; Table 2). This threshold is at the lower limit of the 30 to 300 plots recommended for an average binomial model of 6 independent variables (Peduzzi et al. 1996; Vittinghoff and McCulloch 2007). For these species, we characterized their pathway and time since introduction, and their continent of origin (Table 2).

\section{The models}

We used Generalized Linear Models (GLMs) to explain the relation between the response variables and land-cover variables for the years 1956, 1991 and 2007. Models were compared using the Akaike's Information Criterion corrected for a large number of predictors or small sample size (AICc) (Burnham and Anderson 2002). Lower AICc indicates better fit of the model. First, we selected the best models for each response variable considering the covariates transect length, climate variables, percentage of protected area, and percentage of wetland and dunes habitats (base models). Second, we implemented separately the models with human land-cover variables for each 
year including as fixed variables those selected in the previous base model (land-cover models). For this second type of model, we implemented four variants: all land-cover variables, only cropland, only plantations and only urban. All variants were used for the community level of invasion while for each species we only tested the models related to their main pathway: cropland for agriculture, plantations for forestry, urban for gardening and all variants for unintentionally. Third, we compared the goodness of fit of the best land-cover models for each year. Better fit of models considering land-cover variables for 1956 or 1991 than models for 2007 indicates evidence of invasion or extinction debt related to human-driven landscape alteration (Essl et al. 2011; Lira et al. 2012).

We modelled the error terms of the GLMs explaining overall non-native presence and the occurrence of most frequent species with a Bernoulli distribution whereas for non-natives richness we used a Poisson distribution. Poisson models did not show over-dispersion. All predictors were standardized to facilitate interpretation of model coefficients. Preliminary analyses using Moran's Index indicated low spatial autocorrelation in the models' residuals $(\mathrm{I}<0.3)$ (Fig. A2). Furthermore, adopting any method to reduce autocorrelation (e.g. Dormann et al., 2007) could bias our results as most of them consider adding covariates that are very likely to correlate with the land-cover variables of interest (e.g. spatial autocovariate; Hawkins 2012). Other methods add to the models different spatial covariates depending on the independent variables used (e.g. eigenvector spatial filtering) (Dormann et al., 2007). Thus, if we compare models with different land-cover data, the covariates will be different and the comparison of models for each year will be biased. Therefore, we proceeded without implementing any strategy to reduce spatial autocorrelation.

\section{Projecting future invasions}

If the best model explaining the invasion metrics includes landscape data from 1956, we can use the same model but fed with data from 2007 to estimate the future invasion potential. This projection assumes that the association with past landscape characteristics and the pool of non-native species available remains constant through time. This is a conservative approach that might underestimate future invasions, as regional pools of non-native species tend to increase over time (e.g. see Giraldo et al. 2015). Following this approach we projected future non-native richness for each coastal cell invaded in 2010-2011. We did not project overall non-native presence as it showed higher association with recent than past land-cover data. Therefore, our projections do not account for new invaded areas in the future (e.g. as the result of further urban development). We used the best model for richness calibrated with land-cover data for 1956 and fed with data for 2007. We also calculated the average richness across all coastal cells invaded in 2010-2011 for the future projection and current values (sampling data). The difference between the projected and current richness reflects the average magnitude of invasion and extinction debts (i.e. the potential mean increase or reduction after 2011).

\section{RESULTS}

\section{Human-driven landscape changes and plant invasions}

From 1956 to 2007 there was an average reduction of 8.7\% in cropland area in the whole set of sampled cells (Fig. 2, Fig. A3). In contrast, there was a subtle increase of $0.24 \%$ in forest plantation area and an increment of 3\% and 10.7\% for high-density urban and low-density urban areas, 
respectively. These trends were less evident from 1991 to 2007. In total we found 60 non-native species. At least one non-native species was identified in $45 \%$ of the 809 sampled cells. Non-native richness per cell was $2.08 \pm 0.08$ (mean \pm standard error in 362 invaded cells), with 10 species as the maximum. The most frequent species and their main introduction traits are shown in Table 2.

Overall non-native presence (i.e. presence of at least one non-native species) was best explained by the cropland model for 1956 and the urban model for 2007 (Table 3 and A3). The relatively higher fit of the urban model led the full land-cover model to show higher association with current landcover variables than with past landscape composition. In contrast, the best model explaining nonnative richness included the land-cover variables of 1956 (Table 3 and A3). Separately for each land-cover variable, forest plantation and urban models were better for 1956.

We distinguished four groups of the most frequent species considering their association with present and past landscape composition (Table 4). 1) Plants native to America, with a long residence time (since the $16^{\text {th }}-19^{\text {th }}$ centuries), and associated with cropland area of 1956 (Opuntia dillenii KerGawl. Haw., Agave spp. and Yucca aloifolia L. ). 2) Species native to South Africa, which were introduced in the early $20^{\text {th }}$ Century, and associated with old urban area (Arctotheca calendula L.).

3) Plants native to Australia and South Africa, with medium residence time (since the $19^{\text {th }}$ century), and related to recent altered area (Eucalyptus spp., Acacia saligna (Labill.) H. Wendl. and Carpobrotus edulis L.). Specifically, Eucalyptus occurrence was associated with current forest plantation area while Acacia and Carpobrotus were related to urban areas. 4) Finally, Conyza bonariensis (L.) Cronq. and Solanum sodomeum L. occurrence showed no association with landcover variables in any year.

\section{Projecting future invasions}

At the community level, only current non-native richness showed higher association with past landcover variables than with recent ones (Table 3). We used the model calibrated with land-cover data from 1956 but fed with data from 2007 (Table A3) to predict future non-native richness in all cells with at least one non-native species in 2010-2011 (date of sampling). The projection produced species gain and loss across all the study area in comparison with the current richness found (Fig. 3 ), although the overall is slightly positive (mean 0.019, SE 0.001). The projection showed spatial cluster of cells with similar trends (e.g. richness increase in the West of the study area or richness decrease west to Doñana area). Due to the importance of urban area in our projection models (see Table 3), richness change was higher in cells with higher increase in urban area (\% change) between 1956 and 2007 (linear model: $\beta$ 0.012, $\mathrm{p}<0.01$ ) but not to crop or plantation change (Fig A4; crop $\beta$ : -0.00008, $\mathrm{p}>0.05$; plantations $\beta$ : $-0.049, \mathrm{p}>0.05$ ).

\section{DISCUSSION}

We found higher association between non-native richness and past landscape composition than recent characteristics. This pattern suggests that recently altered areas exhibit an overall invasion debt that will result in a greater non-native richness in the future. Other studies have reported invasion debts at wide spatial contexts and accounting for different drivers (Essl et al., 2011, 2012; Vilà \& Ibáñez, 2011; but see Catford et al., 2011). Essl et al., (2011) showed that the number of 
non-native species per country in Europe is more closely related to indicators of socioeconomic activity from the past century than to those from the last decade. Similarly, other studies have reported invasion to be associated with land-use legacies at the local scale (Doménech et al. 2005; Malavasi et al. 2014). For instance, secondary forests and scrublands resulting from crop abandonment generally are more invaded than undisturbed ones (Vilà et al. 2003; Aragón and Lobo 2012). These findings suggest that plant invasions are closely linked to the temporal dynamics of human activities across a wide range of spatial scales.

Our study also reveals the complex response of plant invasions to landscape change across time. First, because the association of the studied plant invasion metrics (i.e. overall non-native presence and non-native richness in invaded plots) with landscape legacy is not homogeneous. Overall nonnative presence was not associated to the historical landscape, likely due to the high probability that at least one non-native species might become established relatively soon after landscape change. In contrast, non-native species richness was related to historical (1956) landscape composition considering full models (i.e. all land-cover variables per year). Increasing richness in areas altered in the past might be related to the temporal accumulation of non-native plants in urban areas (e.g. gardens) that eventually may escape and establish in natural areas. This hypothesis is supported by the positive association of current non-natives richness with the abundance of long-standing urban areas since 1956. Further studies of the invasion debt concept could take into account other invasion metrics. For instance, the accumulated abundance of invasive species may show a stronger signal of invasion debt than richness due to time-lags between introduction and spread (e.g. Kowarik et al., 1995; Crooks, 2005).

The high variability in time since introduction of particular non-native species challenges the understanding of invasion debt. Unlike immigration credit in native species, invasion debt is strongly affected by the high dynamism of the non-native species pool, constantly enriched by newcomers (e.g. Giraldo-Beltrán et al. 2015). Non-native species composition and their associated introduction events in the study region have changed over time (Table 4), as reported in other regions (Pyšek et al., 2003). Indeed, the overall invasion debt in an area is the outcome of the response time-lags of the species introduced, which might include extinctions and invasion debts. These responses can be related to the species' biological attributes and their characteristics of introduction. Among our study species, early introduced ones such as Opuntia, Agave and Yucca were widely used in agriculture, mostly as green fences or fibre crops and to a lesser extent as ornamentals. Consequently, these species might have undergone their maximum establishment and spread in past cropland-dominated landscapes (see cropland model for overall non-native presence in Table 3). As these species' pathway is associated to a declining land cover (see crop area in Fig. 2), their populations might be decreasing and drive eventually into a local extinction debt. On the other hand, these species are still used in new agricultural areas and are able to colonize and persist in semi natural habitats (e.g. Opuntia spp. in Vilà et al. 2003). These non-exclusive hypotheses suggest the likely existence of both invasion and extinction debts depending on the local trends in landscape configuration. Among the species associated to other pathways such as gardening (e.g. Carpobrotus, Arctotheca and Acacia), forestry (e.g. Eucalyptus) or dune fixation (e.g. Carpobrotus), only Arctotheca occurrence was associated with long-standing urban areas, while the occurrence of the rest of species were related to recently altered areas. Carpobrotus and Acacia 
might have rapidly established in natural areas due to their recently increasing usage in gardening and the resulting increase of propagule pressure. The association of Artotheca occurrence with longstanding rather than with recent urban areas is suprising, as this species can successfully disperse by wind or animals (Sanz-Elorza et al. 2004) and it is still found in recent gardens. Thus, it is very likely that natural dispersal mechanisms might play a secondary role in the current spread of this non-native species. These findings confirm that invasion debt is largely species dependent.

Therefore, to successfully identify invasion debt it is fundamental to choose the adequate propagule pressure proxies and time spans based on the particularities of each non-native species (Ficetola et al. 2010).

Past landscape composition was the best predictor of current non-native richness in the study area. Thus, we used this model but fed with current land-cover data to estimate the balance between invasion and extinction debt yet to occur. Our model predicted on average a slight non-native richness increase across the study area, reflecting a potential but weak invasion debt. This was higher in areas with more urban development between 1956 and 2007. If the debt is "paid", these areas might receive more non-native species in the future. Nevertheless, human activity promoting or constraining non-native species invasion might change over time. This variability challenges our future projections based on a constant association between invasion levels and past landscape composition through time. Thus, to predict invasion levels at local scale we assume that in the following decades the pool of non-natives at regional scale will be the same, or at least will behave similarly to the already established species. If land-uses or the nursery trade suffer major and sudden changes, the projection of invasion debt may be challenging.

\section{Concluding remarks}

Temporal dynamics is increasingly considered a key component in biological invasions (DeGasperis and Motzkin 2007; Ficetola et al. 2010; Aikio et al. 2012). Nevertheless, among the different approaches to studying this component, the invasion debt has rarely been explored in detail. In the present work, we demonstrate how invasion debt can be a useful approach to highlight the intrinsic time-lag component of biological invasions and to identify potential areas under high invasion risk in the near future. We identify three main characteristics of the invasion debt concept. First, invasion debt is always defined with a baseline scenario related to any factor that might affect the process of invasion (e.g. landscape change or trade for introduction). Second, invasion debt can be applied to invasion metrics at community (e.g. non-native richness) and species (e.g. occurrence) levels. In fact, both levels interact as the overall invasion debt of an area is based on the invasion and extinction debts of the available pool of non-native species. Finally, invasion debt is a powerful concept for highlighting time-lags in biological invasions for managers and the general public. Time-lags might result in a potential mismatch between human perceptions and the actual expansion rate of invasive species (Clavero 2014), ultimately causing a delay in the awareness of the invasion problem and in management efforts. Using the invasion debt concept we can spatially project the future level of invasion by relying on models calibrated with past land-cover data but fed with recent data (Ficetola et al. 2010). This approach is useful for identifying areas under high risk of future invasion when there is a significant relationship between invasion and land-cover data (e.g. Ficetola et al., 2010). Therefore, we advocate the systematic use of past landscape characteristics in the modelling of biological invasions. Not accounting for the existence of invasion debt and the dynamic character of invasions (e.g. changing pool of arriving species) could lead to the underestimation of the invasion risk associated with landscape alteration (Crooks 2005) and to 
delayed management interventions that may be less cost-effective (Essl et al. 2015).

Acknowledgements - We thank J.P. González-Varo, E. Revilla, R. Early, N. Roura-Pascual, and two anonymous reviewers for their fruitful comments on the manuscript. We also thank E. Manzano and J.L. Espinar for their contribution during field work. This research was partially funded by the Severo Ochoa Program for Centres of Excellence in R+D+I (SEV-2012-0262), the Spanish Ministerio de Ciencia e Innovación projects Consolider-Ingenio MONTES (CSD2008-00040), RIXFUTUR (CGL2009-7515), and IMPLANTIN (CGL 2015-65346-R), and the Junta de Andalucía projects RNM-4031 and P06/RNM/02030.

\section{SUPPLEMENTARY MATERIAL}

\section{Appendix A}

Table A1-A2: Correlation table among predictors

Figure A1: Association among non-native species metrics and predictors at each spatial extent.

Figure A2: Moran's Index for models explaining non-natives metrics.

Figure A3: Scatter plots for the percentages of cropland and low-density urban areas.

Table A3: Standardized coefficients of the best models explaining the level of plant invasion.

\section{REFERENCES}

Aikio S, Duncan RP, Hulme PE (2010) Lag-phases in alien plant invasions: separating the facts from the artefacts. Oikos 119, 370-378.

Aikio S, Duncan RP, Hulme PE (2012) The vulnerability of habitats to plant invasion: disentangling the roles of propagule pressure, time and sampling effort. Glob Ecol Biogeogr 21:778-871. doi: 10.1111/j.14668238.2011.00711.x

Aragón P, Lobo JM (2012) Predicted effect of climate change on the invasibility and distribution of the Western corn root-worm. Agric For Entomol 14:13-18. doi: 10.1111/j.1461-9563.2011.00532.x

Basnou C., Iguzquiza J., Pino J. (2015) Examining the role of landscape structure and dynamics in alien plant invasion from urban Mediterranean coastal habitats. Landscape and Urban Planning. 136: 156-164.

Bennett JR, Vellend M, Lilley PL, et al (2012) Abundance, rarity and invasion debt among exotic species in a patchy ecosystem. Biol Invasions 15:707-716. doi: 10.1007/s10530-012-0320-z

Burnham KP, Anderson DR (2002) Model selection and multimodel inference: a practical information-theoretic approach, Second edition. Springer-Verlag NY, New York, USA

Catford JA, Vesk PA, White MD, Wintle BA (2011) Hotspots of plant invasion predicted by propagule pressure and ecosystem characteristics. Divers Distrib 17:1099-1110. doi: 10.1111/j.1472-4642.2011.00794.x

Cavanilles AJ (1803) Descripción de las plantas que Don Antonio Josef Cavanilles demostró en las lecciones públicas del año 1802.

Clavero M (2014) Shifting baselines and the conservation of non-native species. Conserv Biol 28:1434-1436. doi: 10.1111/cobi.12266

Colmeiro M (1874) Plantas crasas de España y Portugal. 
Cousins, S.A.O. (2009) Extinction debt in fragmented grasslands: paid or not? Journal of Vegetation Science, 20 , 3-7.

Coutinho AX (1939) A Flora de Portugal, $2^{\mathrm{a}}$ edn. Lisboa

Cristofoli S, Piqueray J, Dufrêne M, et al (2010) Colonization Credit in Restored Wet Heathlands. Restor Ecol 18:645655. doi: 10.1111/j.1526-100X.2008.00495.x

Crooks JA (2005) Lag times and exotic species: The ecology and management of biological invasions in slow-motion. Ecoscience 12:316-329. doi: 10.2980/i1195-6860-12-3-316.1

DeGasperis BG, Motzkin G (2007) Windows of opportunity: historical and ecological controls on berberis thunbergii invasions. Ecology 88:3115-3125. doi: 10.1890/06-2014.1

Doménech R, Vila M, Pino J, Gesti J (2005) Historical land-use legacy and Cortaderia selloana invasion in the Mediterranean region. Glob Change Biol 11:1054-1064. doi: 10.1111/j.1365-2486.2005.00965.x

Dormann CF, McPherson JM, Araújo MB, et al (2007) Methods to account for spatial autocorrelation in the analysis of species distributional data: a review. Ecography 30:609-628. doi: 10.1111/j.2007.0906-7590.05171.x

Essl F, Dullinger S, Rabitsch W, et al (2011) Socioeconomic legacy yields an invasion debt. Proc Natl Acad Sci 108:203-207. doi: 10.1073/pnas.1011728108

Essl F, Dullinger S, Rabitsch W, et al (2015) Historical legacies accumulate to shape future biodiversity in an era of rapid global change. Divers Distrib 21:534-547. doi: 10.1111/ddi.12312

Essl F, Mang T, Moser D (2012) Ancient and recent alien species in temperate forests: steady state and time lags. Biol Invasions 14:1331-1342. doi: 10.1007/s10530-011-0156-y

Ficetola GF, Maiorano L, Falcucci A, et al (2010) Knowing the past to predict the future: land-use change and the distribution of invasive bullfrogs. Glob Change Biol 16:528-537. doi: 10.1111/j.1365-2486.2009.01957.x

Gassó N, Sol D, Pino J, et al (2009) Exploring species attributes and site characteristics to assess plant invasions in Spain. Divers Distrib 15:50-58.

Gavier-Pizarro GI, Radeloff VC, Stewart SI, et al (2010) Housing is positively associated with invasive exotic plant species richness in New England, USA. Ecol Appl 20:1913-1925. doi: 10.1890/09-2168.1

Giraldo-Beltrán, P., Andreu, J., Pino, J. 2015 Exploring changes in the invasion pattern of alien flora in Catalonia (NE of Spain) from large datasets. Biol Invasions 17: 3015-3028

González-Moreno P, Diez JM, Ibáñez I, et al (2014) Plant invasions are context-dependent: multiscale effects of climate, human activity and habitat. Divers Distrib 20:720-731. doi: 10.1111/ddi.12206

González-Moreno P, Gassó N, Pino J, Vilà M (2013a) Landscape context modulates plant invasions in Mediterranean forest edges. Biol Invasions 15:547-557. doi: 10.1007/s10530-012-0306-X

González-Moreno P, Pino J, Carreras D, et al (2013b) Quantifying the landscape influence on plant invasions in Mediterranean coastal habitats. Landsc Ecol 28:891-903. doi: 10.1007/s10980-013-9857-1

Gracia FJ, Alonso C, Del Río L, et al (2011) Las dunas del litoral gaditano. In: Sanjaume E, Gracia FJ (eds) Las dunas de España. Sociedad Española de Geomorfología, Madrid, España,

Guillot D, Van der Meer P, Laguna E, Rosselló JA (2008) El género Agave L. en la flora alóctona valenciana. Monogr Rev Bouteloua 3:94.

Hahs, A.K., McDonnell, M.J., McCarthy, M.A., Vesk, P.A.,Corlett, R.T., Norton, B.A., Clemants, S.E., Duncan, R.P., Thompson, K., Schwartz, M.W. \& Williams, N.S.G. (2009) A global synthesis of plant extinction rates in urban areas. Ecology Letters, 12, 1165-1173.

Hawkins BA (2012) Eight (and a half) deadly sins of spatial analysis. J Biogeogr 39:1-9. doi: 10.1111/j.13652699.2011.02637.x 
Jackson ST, Sax DF (2010) Balancing biodiversity in a changing environment: extinction debt, immigration credit and species turnover. Trends Ecol Evol 25:153-160. doi: 10.1016/j.tree.2009.10.001

Keeley Je, Baer-Keeley M \& Fotheringham CJ (2005) Alien plant dynamics following fire in Mediterranean climate California shrublands. Ecological Applications 15, 2109-2125.

Kowarik I (1995) Time lags in biological invasions with regard to the success and failure of alien species. In: Pyšek P, Prach K, Rejmánek M, Wade M (eds) Plant invasions: general aspects and special problems. SPB Academic Publishing, Amsterdam, The Netherlands, pp 15-38

Krauss, J., Bommarco, R., Guardiola, M., Heikkinen, R.K.,Helm, A., Kuussaari, M., Lindborg, R., € Ockinger, E., Pärtel, M., Pino, J., Poyry, J., Raatikainen, K.M., Sang, A., Stefanescu, C., Teder, T., Zobel, M. \& SteffanDewenter, I. (2010) Habitat fragmentation causes immediate and time-delayed biodiversity loss at different trophic levels. Ecology Letters, 13, 597-605.

Kuussaari M, Bommarco R, Heikkinen RK, Helm A, Krauss J, Lindborg R, Öckinger E, Pärtel M, Pino J, Rodà F, Stefanescu C, Teder T, Zobel M, Steffan-Dewenter I (2009) Extinction debt: a challenge for biodiversity conservation. Trends Ecol. Evol. 24, 564-571.

Lira PK, Ewers RM, Banks-Leite C, et al (2012) Evaluating the legacy of landscape history: extinction debt and species credit in bird and small mammal assemblages in the Brazilian Atlantic Forest. J Appl Ecol 49:1325-1333. doi: 10.1111/j.1365-2664.2012.02214.x

Malavasi M, Carboni M, Cutini M, et al (2014) Landscape fragmentation, land-use legacy and propagule pressure promote plant invasion on coastal dunes: a patch-based approach. Landsc Ecol 29:1541-1550. doi: 10.1007/s10980-014-0074-3

Martínez F., Montero G, Ruiz-Peinado R, et al (2004) Geobotánica e historia de los pinares de pino piñonero. Junta de Andalucía, Sevilla, Spain

Moreira JM, Gámez-Ramírez M, Caturla-Montero C, et al (2010) Mapa de usos y coberturas vegetales del suelo de Andalucía. Junta de Andalucía, Sevilla, Spain

Ohlemüller R, Walker S, Bastow Wilson J (2006) Local vs regional factors as determinants of the invasibility of indigenous forest fragments by alien plant species. Oikos 112:493-501. doi: 10.1111/j.00301299.2006.13887.x

O’rourke KH, Williamson JG (2004) Once more: When did globalisation begin? Eur Rev Econ Hist 8:109-117. doi: $10.1017 / \mathrm{S} 1361491604001078$

Pärtel M, Szava-Kovats R, Zobel M. (2011) Dark diversity: shedding light on absent species. Trends Ecol Evol.26: 1248

Peduzzi P, Concato J, Kemper E, et al (1996) A simulation study of the number of events per variable in logistic regression analysis. J Clin Epidemiol 49:1373-1379. doi: 10.1016/S0895-4356(96)00236-3

Pino J., Arnan X., Rodrigo A., Retana J. (2013) Post-fire invasion and subsequent extinction of Conyza spp. in Mediterranean forests is mostly explained by local factors. Weed Research. 53: 470-478.

Piqueray J, Cristofoli S, Bisteau E, et al (2011) Testing coexistence of extinction debt and colonization credit in fragmented calcareous grasslands with complex historical dynamics. Landsc Ecol 26:823-836. doi: 10.1007/s10980-011-9611-5

Polce, C., Kunin, W.E., Biesmeijer, J.C., Dauber, J. \& Phillips, O.L. (2011) Alien and native plants show contrasting responses to climate and land use in Europe. Global Ecology and Biogeography, 20, 367-379.

Pyšek P, Prach K, Smilauer P (1995) Relating invasion success to plant traits: an analysis of the Czech alien flora. In: Pyšek P (ed) , In: Prach K (ed), In: Rejmánek M (ed), In: Wade M (ed) Plant invasions - general aspects and special problems. Academic Publishing, Amsterdam, The Netherlands, pp. 39-60. 
Pyšek P, Sádlo J, Mandák B, Jarošík V (2003) Czech alien flora and the historical pattern of its formation: what came first to Central Europe? Oecologia 135:122-130. doi: 10.1007/s00442-002-1170-7

Quer J (1762) Flora Española. ó Historia de las plantas que se crian en España. Madrid, España

Ramón-Laca L (1999) Las plantas americanas en la obra de Charles de l’Ecluse: primeras citas.

Sanz-Elorza M, Dana ED, Sobrino E (2004) Atlas de las plantas alóctonas invasoras en España. Dirección General para la Biodiversidad, Madrid

Sobrino E, Sanz-Elorza M, Dana ED, González-Moreno A (2009) Invasibility of a coastal strip in NE Spain by alien plants. J Veg Sci 13:585-594. doi: 10.1111/j.1654-1103.2002.tb02085.x

Tilman D, May RM, Lehman CL, Nowak MA (1994) Habitat destruction and the extinction debt. Nature 371, 65-66.

Valdés B, Talavera S, Fernández-Galiano E (1987) Flora vascular de Andalucía occidental. Ketres Barcelona.

Vilà M, Burriel JA, Pino J, et al (2003) Association between Opuntia species invasion and changes in land-cover in the Mediterranean region. Glob Change Biol 9:1234-1239. doi: 10.1046/j.1365-2486.2003.00652.x

Vilà M, Ibáñez I (2011) Plant invasions in the landscape. Landsc Ecol 26:461-472.

Vittinghoff E, McCulloch CE (2007) Relaxing the Rule of Ten Events per Variable in Logistic and Cox Regression. Am J Epidemiol 165:710-718. doi: 10.1093/aje/kwk052

Zuur A.F., Ieno E.N., Walker N.J., Saveliev A.A., Smith G.M., 2009. Mixed Effects Models and Extensions in Ecology with R. Springer. 
Table 1: Variables considered in the analyses. For Human-driven landscape alteration, protection and habitat variables we indicate the buffer distance used (i.e. spatial extent). In bold, the final list of variables included in the analyses.

\begin{tabular}{lll}
\hline Group & Variable & Spatial extent \\
\hline Human-driven & \% High density urban & $500 \mathrm{~m}$ \\
Landscape alteration & \% Low density urban & $500 \mathrm{~m}$ \\
& \% Cropland & $500 \mathrm{~m}$ \\
& \% Eucalyptus plantations & $500 \mathrm{~m}$ \\
Management & \% Protected area & Within cell \\
Habitat & \% Dunes & Within cell \\
& \% Wetlands & Within cell \\
Climate & Annual Mean Temperature; Mean Diurnal Range, Isothermality; & \\
& Temperature Seasonality; Max Temperature of Warmest Month; & \\
& Min Temperature of Coldest Month; Temperature Annual & \\
& Range; Mean Temperature of Wettest Quarter; Mean & \\
& Temperature of Driest Quarter; Mean Temperature of Warmest & \\
& Quarter; Mean Temperature of Coldest Quarter; Annual & \\
& Precipitation; Precipitation of Wettest Month; Precipitation of & \\
& Driest Month; Precipitation Seasonality; Precipitation of & \\
& Wettest Quarter; Precipitation of Driest Quarter; Precipitation & \\
& of Warmest Quarter; Precipitation of Coldest Quarter & \\
& & \\
\end{tabular}


Table 2: List of the most frequent non-native species with record of the number of cells in which they were found (total number of cells $=809$ ).

\begin{tabular}{|c|c|c|c|c|c|}
\hline Species & Pathway & Origin & Introduction & Reference & Cells \\
\hline Agave spp. & $\begin{array}{l}\text { Agriculture } \\
\text { Gardening }\end{array}$ & America & $\begin{array}{l}1576 \\
\text { (Spain) }\end{array}$ & $\begin{array}{l}\text { (Quer 1762; Ramón- } \\
\text { Laca 1999; Guillot et al. } \\
\text { 2008) }\end{array}$ & 61 \\
\hline Opuntia dillenii & $\begin{array}{l}\text { Agriculture } \\
\text { Gardening }\end{array}$ & America & $\begin{array}{l}1874 \\
\text { (Study area) }\end{array}$ & (Colmeiro 1874) & 82 \\
\hline Yucca aloifolia & $\begin{array}{l}\text { Agriculture } \\
\text { Gardening }\end{array}$ & America & $\begin{array}{l}1803 \\
\text { (Spain) }\end{array}$ & (Cavanilles 1803) & 29 \\
\hline Arctotheca calendula & Gardening & $\begin{array}{l}\text { South } \\
\text { Africa }\end{array}$ & $\begin{array}{l}1925 \\
\text { (Study area) }\end{array}$ & (Sanz-Elorza et al. 2004) & 59 \\
\hline Acacia saligna & Gardening & Australia & $\begin{array}{l}19^{\text {th }} c . \\
\text { (Spain) }\end{array}$ & Sanz-Elorza et al. 2004 & 39 \\
\hline Carpobrotus edulis & $\begin{array}{l}\text { Gardening } \\
\text { Restoration }\end{array}$ & $\begin{array}{l}\text { South } \\
\text { Africa }\end{array}$ & $\begin{array}{l}1900 \\
\text { (Study area) }\end{array}$ & Sanz-Elorza et al. 2004 & 113 \\
\hline Eucalyptus spp. & Forestry & Australia & $\begin{array}{l}\text { Mid } 19^{\text {th }} \text { c. } \\
\text { (Spain) }\end{array}$ & Sanz-Elorza et al. 2004 & 40 \\
\hline Conyza bonariensis & Unintentionally & America & $\begin{array}{l}\text { Early } 19^{\text {th }} \text { c. } \\
\text { (Spain) }\end{array}$ & Sanz-Elorza et al. 2004 & 38 \\
\hline Solanum sodomeum & Unintentionally & $\begin{array}{l}\text { South } \\
\text { Africa }\end{array}$ & $\begin{array}{l}1939 \\
\text { (Study area) }\end{array}$ & (Coutinho 1939) & 38 \\
\hline
\end{tabular}


Table 3: Goodness of fit of the models explaining current plant invasion (i.e. overall non-native presence and richness in invaded cells) considering land-cover variables for 1956, 1991 and 2007. For each plant invasion metric, we present the relative AICc (actual AICc minus the minimum AICc for each metric) of the null model, the base model (habitat, climate and protected area variables) and four model variants with the base model plus the land-cover variables (cropland, Eucalyptus plantations, urban areas and all together). Lower relative AICc values indicate better goodness of fit. The bold values in each row indicate best models with similar support (within 4 AICc) for each model variant and plant invasion metric across the three years. In brackets, the minimum AICc obtained for each plant invasion metric. Evidence of invasion debt is supported when the 1956 model is the best across all years for the same model variant (row).

\begin{tabular}{|c|c|c|c|}
\hline & 1956 & 1991 & 2007 \\
\hline \multicolumn{4}{|c|}{ Overall presence (Min AICc: 1023.7) } \\
\hline All & 4.8 & 12.4 & $\mathbf{0 . 0}$ \\
\hline Urban & 12.3 & 15.1 & 0.0 \\
\hline Cropland & 16.1 & 23.4 & 23.4 \\
\hline Plantation & 23.4 & 21.0 & 23.4 \\
\hline \multicolumn{4}{|c|}{ Base: 23.4; Null: 90.8} \\
\hline \multicolumn{4}{|c|}{ Richness (Min. AICc: 1174.5) } \\
\hline All & 0.0 & 9.4 & 7.1 \\
\hline Urban & 4.6 & 9.4 & 10.0 \\
\hline Plantation & 5.5 & 10.0 & 7.1 \\
\hline Cropland & 10.0 & 10.0 & 10.0 \\
\hline \multicolumn{4}{|c|}{ Base: 10.0; Null: 37.5} \\
\hline
\end{tabular}


Table 4: Comparison of the goodness of fit (relative AICc values) of the models explaining the occurrence of the most frequent non-native species (see Table 3 for model details). We only present the most plausible model variants for each species considering its main pathways of introduction (See Table 1 for species-pathways correspondence). Lower AICc values indicate better fit of the models. Bold values indicate best models within 4 AICc (similar support) for each species.

Evidence of invasion debt is supported when the 1956 model is the best across all years for the same model variant (row). Species are grouped (1 to 4) based on their invasion debt pattern (see results).

\begin{tabular}{|c|c|c|c|c|}
\hline Garden, \& agri, & 1956 & 1991 & 2007 & Group \\
\hline \multicolumn{4}{|c|}{ Agave spp. (Min. AICc: 406.2) } & 1 \\
\hline All & $\mathbf{0}$ & 7.79 & 5.6 & \\
\hline Cropland & 2.09 & 7.79 & 7.79 & \\
\hline Urban & 6.56 & 7.79 & 5.6 & \\
\hline \multicolumn{5}{|c|}{ Base: 7.79; Null: 28.5} \\
\hline \multicolumn{4}{|c|}{ Opuntia dillenii (Min. AICc: 433.1) } & 1 \\
\hline All & $\mathbf{0}$ & 11.21 & 11.21 & \\
\hline Cropland & 3.43 & 11.21 & 11.21 & \\
\hline Urban & 9.26 & 11.21 & 11.21 & \\
\hline \multicolumn{5}{|c|}{ Base: 11.21; Null:99.71 } \\
\hline \multicolumn{4}{|c|}{ Yucca aloifolia (Min. AICc:220.7) } & 1 \\
\hline All & $\mathbf{0}$ & 7.31 & 11.17 & \\
\hline Cropland & 6.65 & 16.87 & 16.87 & \\
\hline Urban & 12.27 & 9.36 & 11.54 & \\
\hline \multicolumn{5}{|c|}{ Base: 16.87; Null: 31.31} \\
\hline Gardening & 1956 & 1991 & 2007 & \\
\hline \multicolumn{4}{|c|}{ Arctotheca calendula (Min. AICc: 362.4 ) } & 2 \\
\hline Urban & $\mathbf{0}$ & 5.18 & 7.22 & \\
\hline \multicolumn{5}{|c|}{ Base: 7.22; Null:62.1 } \\
\hline \multicolumn{4}{|c|}{ Acacia saligna (Min. AICc: 247.9) } & 3 \\
\hline Urban & 18.71 & 9.61 & $\mathbf{0}$ & \\
\hline \multicolumn{5}{|c|}{ Base: 21.83; Null:66.68 } \\
\hline \multicolumn{4}{|c|}{ Carpobrotus edulis (Min.AICc: 587.4) } & 3 \\
\hline Urban & 11.82 & 1.1 & $\mathbf{0}$ & \\
\hline \multicolumn{5}{|c|}{ Base: 18.46; Null: 68.88} \\
\hline Forestry & 1956 & 1991 & 2007 & \\
\hline \multicolumn{3}{|c|}{ Eucalyptus spp. (Min. AICc: 296.2) } & & 3 \\
\hline Plantation & 10.96 & 11.67 & $\mathbf{0}$ & \\
\hline Base & 12.7 & Null & 24.33 & \\
\hline Unintentionally & 1956 & 1991 & 2007 & \\
\hline \multicolumn{4}{|c|}{ Conyza bonariensis (Min. AICc: 146) } & 4 \\
\hline All & $\mathbf{0}$ & 2.77 & 2.77 & \\
\hline Urban & $\mathbf{0}$ & 2.77 & 2.77 & \\
\hline Cropland & 2.77 & 2.77 & 2.77 & \\
\hline Plantation & 2.77 & 2.77 & 2.77 & \\
\hline Base & 2.77 & Null & 162.65 & \\
\hline \multicolumn{4}{|c|}{ Solanum sodomeum (Min. AICc: 297.1) } & 4 \\
\hline All & 3.61 & 0 & 0.6 & \\
\hline Cropland & 3.61 & 3.61 & 3.61 & \\
\hline Plantation & 3.61 & 2.19 & 3.61 & \\
\hline Urban & 3.61 & 1.31 & 0.6 & \\
\hline \multicolumn{5}{|c|}{ Base: 3.61; Null:11.54 } \\
\hline
\end{tabular}



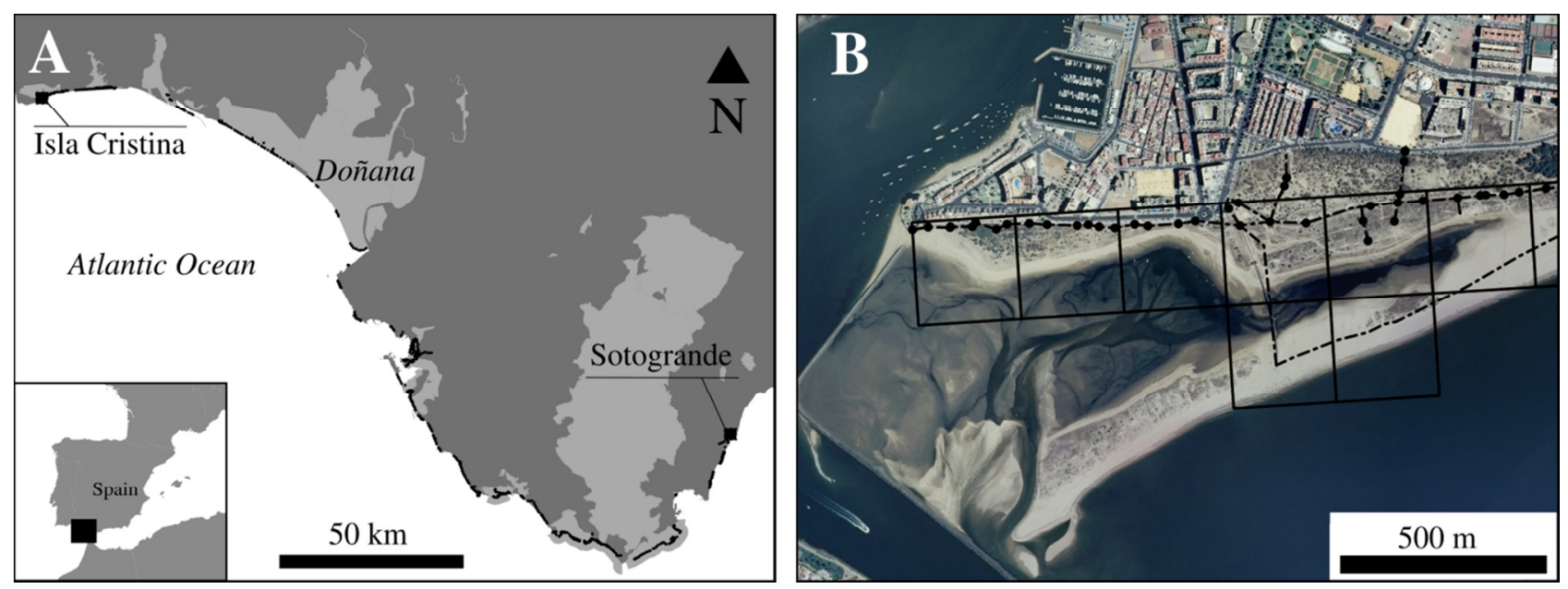

Figure 1: A) Study area on the South western coast of Spain from the villages of Isla Cristina to Sotogrande. Black dots along the coast indicate cells used in the analyses. Light grey polygons delimit protected areas (e.g. Doñana). Left bottom corner shows the location of the study area in Spain. B) Sampling protocol with depiction of the transects (dashed line), occurrence of non-native species (black dots) and 250 x 250 m cells (squares). 


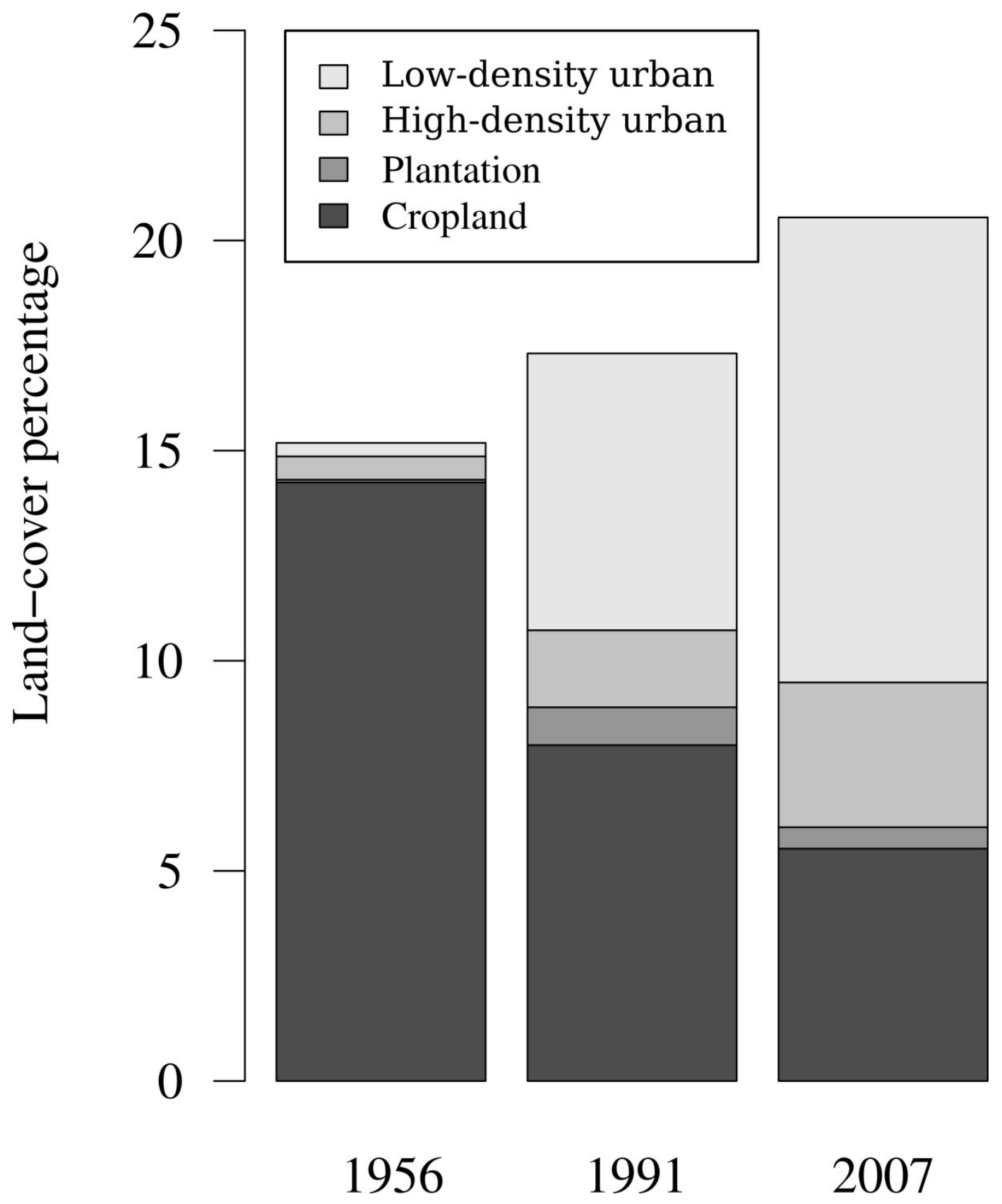

Figure 2: Mean percentage of each land-cover type reflecting human alteration (low-density urban, high-density urban, forest plantation and cropland) in 809 cells (250 x $250 \mathrm{~m}$ ) for 1956, 1991 and 2007. The percentage not accounted for in bars corresponds to land-cover types not associated with human activity. 


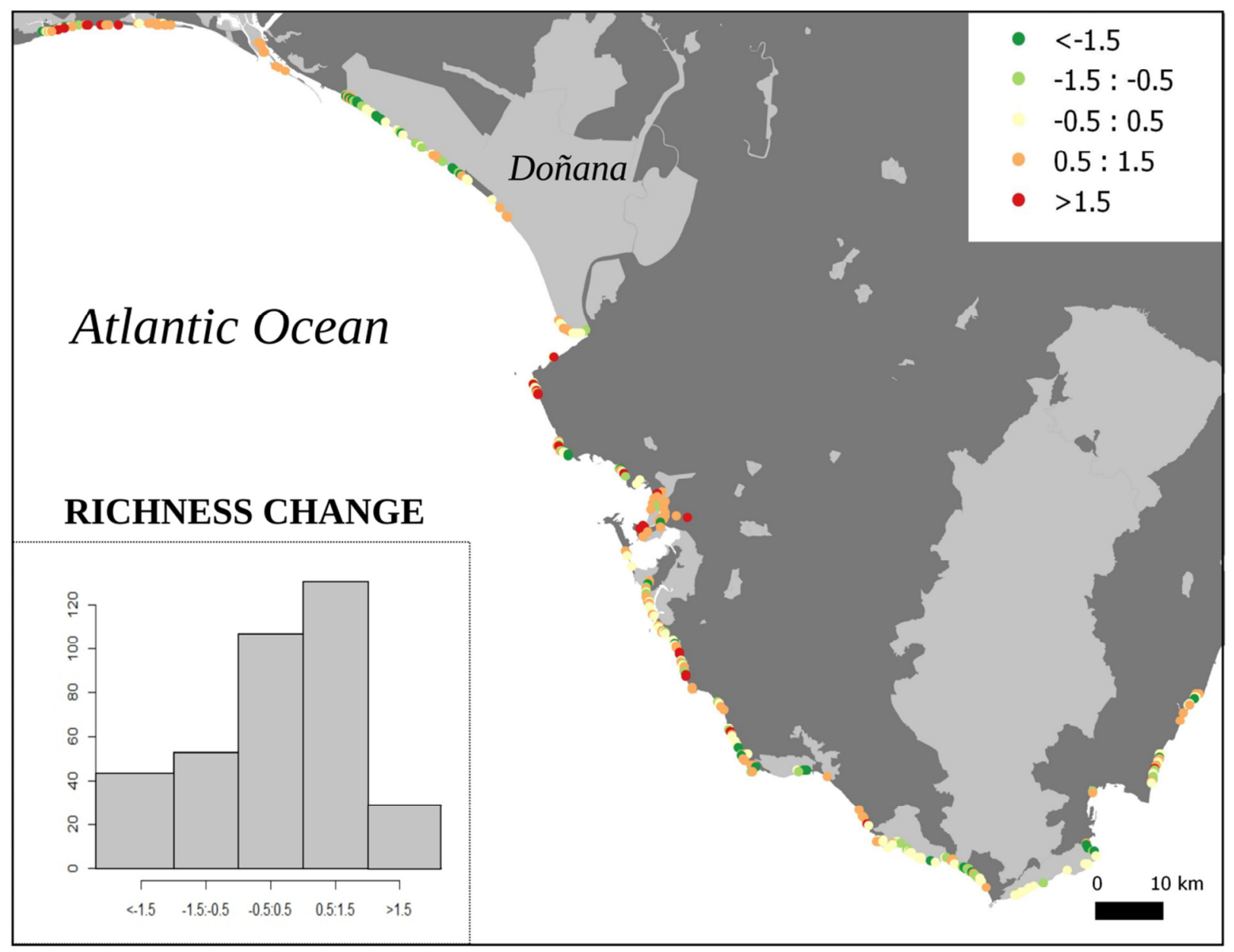

Figure 3: Projection of future non-native plant richness change in $250 \mathrm{~m}$ x $250 \mathrm{~m}$ coastal cells using the best model calibrated with land-cover data from 1956 and fed with 2007 data. Only cells with at least one non-native species in 2010-2011 are considered (date of sampling). Light grey polygons delimit protected areas (name in italic). Left bottom corner box shows the histogram (number of cells) of non-native richness change. 